ское исследование. Авторами статьи приведены данные такого исследования, которое было осуществлено в границах Столичного макрорайона. В результате установлено, что профессионально-образовательный уровень является одним из определяющих факторов, по которым в общественном восприятии следует относить к среднему классу.

Ключевые слова: средний класс, критерии среднего класса, Столичный макрорайон.

Oliinyk Y., Dr. of Economic, Prof., Acad. of National Academy of Sciences of Ukraine,

Pereguda Y.A., PhD Student

Taras Shevchenko National University of Kyiv, Kyiv, Ukraine

\title{
PROFESSIONAL-EDUCATIONAL LEVEL AS THE CRITERIA OF THE MIDDLE-CLASS PARTICIPATION IN THE CAPITAL REGION OF UKRAINE: SOCIAL-GEOGRAPHICAL INVESTIGATION
}

The article reveals the identification problems of the middle class in Ukraine, on the example of the capital's macro-district. It shows that scientific approaches applied in foreign scientific schools cannot be using in Ukrainian conditions because number of reasons. In particular, the low level of income in the country as a whole caused a decline in the acceptable level of income. That is, the sense of term "middle class" in Ukrainian conditions has a completely different context. On the other hand, the Ukrainian national currency has a larger purchasing power, than us dollar has, for example. Therefore, one cannot directly compare the incomes of Ukrainian citizens and the incomes of residents of economically developed countries. In addition, due to the specific nature of the methodological base of Ukrainian state statistics, the state does not collect data on the middle class. Consequently, the identification of the middle class in Ukrainian conditions is an important practical and scientific problem. One of the approaches that makes it possible to circumvent these contradictions is the subjective method, that is, the carrying out of sociological research. The authors of the article present the data of such an investigation, which was made within the frontiers of the Metropolitan macrodistrict. As a result, authors found the vocational and educational level is one of the determining factors, which in the public perception should be attributed to the middle class. Because of the survey, it was established that property criteria, after all, are decisive in identifying the middle class. At the same time, the level of education and profession is important as the level of income. This allows us to conclude that public opinion in Ukraine identifies the middle class not only as a group of people with a certain level of income, but also as a community with high levels of education and self-awareness. For the capital's macro-district of Ukraine, its own characteristics of middle class have few characteristic. Although the income level of the population in this macro-region is the highest, the criteria for identifying the middle class are also high. It is significant that the understanding of the middle class in Ukrainian society has its own specifics. For the Ukrainian class is not required the availability of their own housing or their own car. The level of well-being measured as a whole by the level of income that the household receives.

Key words: middle class, middle class criteria, the capital's macro-district.

http://doi.org/10.17721/1728-2721.2018.70.2

удк $911.5 / .9$

П. Шищенко, д-р геогр. наук, проф.,

О. Гавриленко, канд. геогр. наук, доц.

Київський національний університет імені Тараса Шевченка, Київ

\section{ГЕОЕКОЛОГІЯ В НАУКОВО-ОСВІТНЬОМУ ВИМІРІ}

Розглянуто становлення геоекологічної парадигми, а також різні тлумачення змістовної сутності геоекології. Проаналізовано завдання міждисциплінарної геоекології та її прикладний антропоцентричний аспект, на основі якого мають формуватися планувально-проектні рішення. Розкрито методи оцінних і прогнозних геоекологічних досліджень, що служать установленню ступеня придатності геоекосистем для різних видів діяльності та обґрунтування проектів природокористування. Виходячи з важливості засвоєння студентами знань про дестабілізацію природного середовища як природно-техногенного иілого, обґрунтовано доцільність викладання прикладної геоекології як окремої навчальної дисципліни. Розкрито зміст і послідовність застосування інноваційних активних методів у навчальному процесі, зокрема методу проектів. Наведено приклад проектної діяльності студентів у разі обрання конкретної теми проекту з дисципліни "Геоекологія України".

Ключові слова: геоекосистеми, геоекологічне оцінювання та прогнозування, обґрунтування проектів природокористування, метод проектів, геоекологічна освіта.

Постановка проблеми. Сучасна тенденція екологізації розвитку різних наук спричинила формування нових наукових дисциплін на стику географії та екології, що супроводжується гострими дискусіями щодо їхніх цілей, завдань і змісту. Через різні трактування змістовної сутності геоекології проблема полягає у визначенні її головної мети - застосування екологічного підходу до вивчення географрічного середовища й установлення вимог до його господарського використання. Порівняно з класичною екологією, геоекологія має ширший погляд на природну складову системної взаємодії суспільства і виробництва, що надає їй суттєвих переваг у розробленні шляхів розв'язання нагальних екологічних проблем.

Геоекологія поєднує традиційну географічну прив'язку до просторової диференціації території та екологічний підхід до оптимізації географічного середовища. Установлення придатності геоекосистем для конкретних видів природокористування потребує використання оцінювальних геоекологічних досліджень, де головною проблемою $€$ визначення провідних критеріїв оцінки негативних наслідків різних господарських впливів на природу. Імовірні негативні зміни природного середовища і небезпечні процеси, посилені технічними засобами, потребують розроблення спеціальних прогнозних методів дослідження. Усвідомлення відповідальності за розв'язання геоекологічних проблем сприяє актуалізації екологічної складової національної системи освіти в Україні. Вища освіта потребує якісних змін, розроблення й упровадження новітніх методів і підходів з використанням найкращого зарубіжного досвіду.

Аналіз попередніх досліджень. У наукових працях, присвячених упровадженню екологічного підходу до географічних досліджень, тривають дискусії щодо змістовної сутності, цілей, завдань і змісту геоекології. Зокрема, у праці [11] геоекологія трактується як міждисциплінарна наука, що вивчає незворотні процеси та явища у природному середовищі, зумовлені надмірним антропогенним впливом. Геоекологією ще називають галузь географії, що стосується будь-яких аспектів оптимізації взаємодії суспільства з природою [2]. Також її трактують як науковий напрям, що вивчає екосферу в процесі ії інтеграції із суспільством [5]. На прикладний антропоцентричний аспект геоекології вказується у праці [9]. Найповніший аналіз методологічних аспектів геоекології наведений у [12].

Активно досліджуються питання щодо застосування інноваційних методів у навчальному процесі. Справедливе твердження про те, що для студентів принципово важливим є засвоєння знань про дестабілізацію приро- 
дного середовища як природно-техногенного цілого [12]. Різні тлумачення сутності методу проектів у науковій літературі зводяться переважно до форми організації навчання, технології навчання, засобу досягнення певних якостей і характеристик особистості в навчанні [17]. Не викликає заперечень той фракт, що використання проектного методу забезпечує можливість опанування фрорм самостійної дослідницької діяльності студентів, формує у них відчуття відповідальності за результат своєї діяльності й забезпечує їхню підготовку до природоохоронної роботи [13]. А шляхом від теорії до практики стає поєднання академічних знань із прагматичними за умови дотримання певного балансу на кожному етапі навчання [7].

Постановка завдання. Здорова конкуренція за лідерство у створенні фундаменту для розв'язання геоекологічних проблем сприяє прогресивному розвитку науки. Одним із завдань має бути спрямування екологізації географії на створення комфортного для людини географічного середовища й оптимізацію ландшафтів за допомогою геоекологічних досліджень. Будь-яка екологічна проблема має прив'язку до ландшафтної структури території, а об'єктами оптимізації стають геоекосистеми. Одним із завдань $є$ комплексне оцінювання територіальних ресурсів, що охоплює все їхнє різноманіття, методологічну базу якого остаточно ще не розроблено. Недостатньо розв'язаним питанням $€$ вибір методів геоекологічного прогнозування, що зумовлено наявністю значної їхньої кількості. Основним завданням $\epsilon$ ефрективне використання результатів оцінних і прогнозних геоекологічних досліджень як основи для прийняття проектно-планувальних рішень.

Нерозв'язаною проблемою залишається відсутність єдності між набуттям студентами теоретичних знань і практичних навичок у сучасній вищій освіті. Зважаючи на це, першочерговим завданням стає усвідомлення причинно-наслідкових зв'язків у освітньому процесі. Досі не розроблено єдиної концепції викладання природничо-наукових дисциплін і засвоєння студентами різних курсів і кваліфрікацій геоекологічних знань. Через швидкі темпи надходження геоекологічної інформації форми і методи навчання недостатньо ефективні для ії засвоєння. Зокрема, технологія проектування, яка має на меті інтегрування набутих знань із різних навчальних предметів для досягнення студентами самостійних практичних результатів, упроваджується в навчальний процес доволі повільно.

Виклад основного матеріалу дослідження. Від початку усвідомлення суспільством у другій половині XX ст. концепції оптимізації взаємовідносин людини і середовища її мешкання загальною тенденцією розвитку науки стала екологізація, а між різними науковими галузями навіть виникла своєрідна конкуренція за лідерство у створенні фундаменту для розв'язання екологічних проблем. Екологізацію географії наблизив системний підхід, що став методологічною основою як екології, так і географої. Установлення тісних контактів між екологією рослин і географією сприяло появі вчення про природні зони. Дослідження структури природного середовища потребувало охоплення не лише його біотичної частини, але й неживих компонентів, тобто виходу на позиції вчення про ландшафти.

Екологізація географії активізувалася після доповіді В. Сочави "Географрія і екологія" на V з'їзді Географрічного товариства СРСР (1970), у якій академік звернув увагу на зв'язок географії з екологією людини, підкресливши роль учення про геосистеми в розробці наукових основ оптимізації природного середовища [14]. Ще тісніше зблизили екологію і географію спільні підходи до розв'язання практичних завдань природокористування, що змусило географфію, за висловом Д. Арманда, "ії одним колесом - ландшафтознавством - наїхати на екологію" [1, с. 201]. Екологізація географрічних досліджень виразно виявилася у другій половині 1980-х рр., коли була визнана екологічна парадигма в географії [6]. Водночас подібні процеси відбувалися й у американській географрічній науці [20].

Становлення геоекологічної парадигми супроводжувалося появою значної кількості нових наукових дисциплін еколого-географрічного спрямування, які при цьому не мали чітко окресленого предмета досліджень, теоретичної та практичної значимості. Через це існують різні уявлення про об'єкт, предмет і завдання, а також різні трактування змістовної сутності геоекології (табл. 1), найбільш прийнятним з яких $є$ її інтерпретація як комплексної природничої дисципліни, яка використовує географрічний і екологічний підходи та досліджує геоекосистеми з метою оптимізації довкілля людини [18].

Таблиця 1. Трактування геоекології різними авторами [18]

Визначення геоекології

\begin{tabular}{lll|}
\hline Наука про взаємодію біоценозу з абіотичним середовищем у межах гомогенного ландшафтного ареалу & К. Тролль [16] \\
\hline Міждисциплінарна наука про комфортність географічного середовища й оптимізацію ландшафту & Ф. Мільков [10] \\
\hline $\begin{array}{l}\text { Наука, що вивчає незворотні процеси та явища у природному середовищі та біосфері, зумовлені інтенси- } \\
\text { вним антропогенним впливом, а також близькі й віддалені в часі наслідки цих впливів }\end{array}$ & $\begin{array}{l}\text { В. Морачевський, } \\
\text { К. Петров [11] }\end{array}$ \\
\hline $\begin{array}{l}\text { Конструктивна природнича наука, покликана оптимізувати взаємодію суспільства з природним географіч- } \\
\text { ним середовищем }\end{array}$ & В. Сочава [14] \\
\hline $\begin{array}{l}\text { Міждисциплінарна природничо-суспільна наука, орієнтована на оптимізацію взаємодії суспільства з його } \\
\text { географічним середовищем, яка досліджує геоекосистеми }\end{array}$ & Г. Бачинський [2] \\
\hline $\begin{array}{l}\text { Область географії, що стосується будь-яких аспектів оптимізації взаємодії суспільства з природою і не } \\
\text { має єдиного матеріального об'єкта дослідження }\end{array}$ & О. Топчієв [15] \\
\hline $\begin{array}{l}\text { Міждисциплінарний науковий напрям, який вивчає екосферу як взаємопов'язану систему геосфер у про- } \\
\text { цесі її інтеграції із суспільством }\end{array}$ & Г. Голубєв [5] \\
\hline Комплекс наук, що вивчають стан географрічної оболонки й певною мірою - геологічного середовища & М. Ясаманов [19] \\
\hline
\end{tabular}

Об'єктом дослідження геоекології є геоекосистеми ділянки ландшафтної сфери Землі, які управляються або контролюються людиною, мають характерні процеси тепло- і вологообміну, біогеохімічні кругообіги, певні види господарської діяльності й соціокультурні відносини [18]. Значною мірою геоекологія спирається на пра- вові основи, які визначають різні види відповідальності за порушення природного середовища, а також на екологічні оцінки і форми стимулювання природоохоронної діяльності. Сутність геоекосистемної концепції полягає в тому, що природне середовище є організованою цілі- 
сністю, складеною з геоекосистем - об'єктів науково обґрунтованої оптимізації.

Метою міждисциплінарної геоекології в найширшому розумінні $€$ оптимізація природокористування на основі дослідження геоекосистемних взаємозв'язків та інтегрування здобутих знань у практику територіального планування і менеджменту. Вужчі завдання геоекології відповідають фраховим спеціалізаціям (аграрна геоекологія, геоекологія містобудування, геоекологія регіонального планування, геоекологія лісового менеджменту тощо).

Якщо геоекологію визначати як систему наук про інтеграцію геосфер і суспільства [4], то об'єктом досліджень стає біосфера, а головною метою - установлення фундаментальних закономірностей ії фрункціонування, зокрема технобіосфери як соціоприродної глобальної екосистеми. Геоекологія $є$ пошуковою наукою, оскільки не лише фріксує поточний екологічний стан, але й досліджує, як він формувався, що підтримує його рівень, і головне - виявляє ймовірні напрями розвитку геоекологічної ситуації в найближчій і віддаленій перспективі. Прикладний антропоцентричний аспект геоекології розкривається в конструктивних розділах комплексної природничої географії [9], на його основі фрормуються планувально-проектні рішення.

Повноцінне геоекологічне дослідження має бути орієнтоване на вивчення суспільних потреб і контроль за практичним упровадженням результатів з подальшою їхньою підтримкою. Важливою сферою практичного застосування результатів геоекологічних досліджень $€$ створення оптимальної структурно-функціональної організації території для обґрунтування різноманітних проектів природокористування. У цих випадках методика геоекологічних досліджень базується на взаємопов'язаних методах - оцінних, прогнозних, управлінських.

Геоекологічне оцінювання передбачає передусім оцінювання ступеня придатності властивостей геоекосистем або їхніх окремих компонентів для конкретного виду природокористування за схемою "вплив - зміни наслідки". Спочатку вивчається вплив діяльності людини на природне середовище, потім оцінюються зміни геоекосистем завдяки цій діяльності, після здійснюється оцінювання наслідків змін для природи, господарства і населення. Об'єктом оцінювання зазвичай $є$ зміни геоекосистем, суб'єктом - види господарської діяльності людини і сама людина. Оцінка негативних наслідків впливу людини на природу базується на виявленні змін середовища мешкання людини. Така оцінка $€$ антропоцентричною, оскільки головним критері$\epsilon м €$ здоров'я населення.

3 метою забезпечення оптимального функціонування геоекосистем, а також попередження вияву надзвичайних екологічних ситуацій широко використовуються прогнозні методи. Геоекологічне прогнозування $€$ науково обґрунтованим передбаченням тенденцій зміни природного середовища і перебігу суспільно-географічних процесів. Зазвичай об'єктами геоекологічного прогнозування $€$ геоекосистеми різних таксономічних рангів, найчастіше локального і регіонального рівнів. У багатьох випадках геоекологічне прогнозування має на меті розроблення уявлень про геоекосистеми майбутнього, їхні докорінні властивості й різноманітні змінні стани, передусім обумовлені діяльністю людини. Одним з найголовніших завдань такого прогнозування $€$ запобігання можливим руйнівним природним процесам, які посилюються технічними засобами, а також створення раціональної структури території, виявлення вторинних впливів і можливих довготривалих змін природного середовища.

Прогнозні дослідження також мають на меті отримання інформації щодо термінів незворотного виснаження природних ресурсів і дигресії природного середовища в разі розміщення тих чи інших об'єктів природокористування. При цьому необхідно визначити не лише прогнозований характер впливу об'єкта на геоекосистеми, але й ті функції природного середовища, які під цим впливом можуть бути порушені. Прогноз має або підтвердити необхідність, можливість і доцільність розміщення на даній території певних господарських об'єктів, або спростувати.

Якщо геоекологічне дослідження орієнтоване на обґрунтування проектів природокористування і створення оптимальної структурно-функціональної організації території, то кінцевою метою застосування оцінних і прогнозних методів дослідження має бути встановлення ступеня придатності геоекосистем або їхніх окремих компонентів для проектованого виду природокористування. Оцінка негативних наслідків господарського впливу на природне середовище, провідними критеріями якої $є$ негативні зміни компонентів геоекосистем і стан здоров'я населення, передбачає дотримання розробленого алгоритму досліджень. Прогнозні геоекологічні дослідження спрямовані на запобігання можливим руйнівним природним процесам, виявлення вторинних антропогенних впливів і спричинених ними довготривалих змін природного середовища. Геоекологічне прогнозування різних масштабних рівнів пов'язане спільною необхідністю узгодження будь-якої діяльності людини 3 критеріями, що забезпечують збереження стабільності географічного середовища. На результатах оцінних і прогнозних геоекологічних досліджень має базуватися прийняття остаточних проектно-планувальних рішень.

Розв'язання означених вище конструктивних завдань геоекологічних досліджень потребує відповідного фаху й освіти дослідників. На географічному факультеті Київського національного університету імені Тараса Шевченка для магістрів першого року навчання викладається дисципліна "Геоекологія України". Оволодіння нею має на меті поглиблення теоретичних геоекологічних знань, формування в майбутніх фрахівців геоекологічного мислення і компетентностей, розуміння ними сутності та причин виникнення численних геоекологічних проблем в Україні та світі. Мета досягається шляхом розв'язання програмних навчальних завдань, зокрема:

- засвоєння базових знань про зміни навколишнього середовища під впливом природних і антропогенних факторів;

- ознайомлення з різними видами територіального планування і проектування;

- оволодіння змістом і методами геоекологічної експертизи проектів;

- поглиблення пізнавальних інтересів, розвиток творчого підходу до розв'язання геоекологічних завдань, самостійне набуття нових знань;

- фрормування геоекологічної культури, навичок дбайливого використання й охорони природних умов i ресурсів;

- використання компетентностей у суспільному житті, професійна орієнтація, самооцінка можливостей особистої участі в розв'язанні проблем. 
Глобальні зміни довкілля виробничою та іншою діяльністю людини та їхні небезпечні наслідки для суспільства зумовили становлення прикладної геоекології - науково-практичного напряму геоекології, що, як і будь-яка інша прикладна галузь знань, підпорядкована безпосереднім вимогам життєдіяльності людини. Пріоритетним завданням прикладної геоекології є попередження можливостей виникнення кризових і надзвичайних геоекологічних ситуацій. Принципово важливим є засвоєння студентами знань про дестабілізацію природного середовища як природно-техногенного цілого [12]. Тому в найближчій перспективі доцільним було б викладання прикладної геоекології як окремої навчальної дисципліни.

Вивчення дисципліни "Геоекологія України" сприяє орієнтації студентів на здобуття фаху менеджера 3 охорони навколишнього середовища, проектувальника, експерта проектів природокористування тощо. Головним завданням при цьому стає пошук шляхів поліпшення засвоєння студентами лекційного матеріалу з подальшою апробацією його на практичних (семінарських) заняттях. Процес навчання слід починати з методологічних основ геоекології, тобто визначення ії̈ місця в системі наук про Землю, а також виділення об'єкта і предмета досліджень. Студенти мають чітко засвоїти, що об'єктами дослідження геоекології $€$ геоекосистеми. При цьому дослідження концентруються на одному предметі - усебічному вивченні параметрів геоекосистем, найбільш значимих для збереження цілісності, стабільності й саморегуляції [3]. Засвоєння змісту навчальної дисципліни передбачає апробацію лекційного матеріалу на практичних і семінарських заняттях із застосуванням інноваційних активних методів у навчальному процесі. Серед останніх, зокрема, метод проектів, упровадження якого дозволяє не лише передавати студентам певні знання, але й вчити їх здобувати ці знання самостійно в тісній співпраці з викладачем.

Метод проектів як освітня технологія виник у 20-х pp. XX ст. у США, де його називали методом проблем. В основі методу лежать ідеї Джона Дьюї - американського фрілософа, психолога, засновника педагогічного прагматизму і реформатора освіти, який започаткував ідеї побудови навчання на активній основі через доцільно-мотивовану діяльність суб'єкта навчання у співвідношенні 3 його особисто визначеним інтересом. Незважаючи на серйозні наукові розробки, єдиного підходу до визначення поняття "метод проектів" поки що не існує. Різні його тлумачення в науковій літературі зводяться переважно до методу навчання, форми організації навчання, технології навчання, засобу досягнення певних якостей і характеристик особистості в навчанні [17].

Проектна технологія передбачає наявність проблеми, що вимагає дослідницького пошуку шляхів її розв'язання за допомогою інтегрованих знань. Специфічною рисою методу $є$ індивідуальна робота за спільно складеним планом, результати якої повинні мати практичну, теоретичну і пізнавальну значимість. Проектна діяльність стимулює зацікавленість суб'єкта навчання певними проблемами, що дозволяє через розв'язання однієї або кількох проблем застосовувати отримані знання на практиці. Отже, шляхом від теорії до практики стає поєднання академічних знань із прагматичними за умови дотримання певного балансу на кожному етапі навчання [7].

Завдяки оптимальному поєднанню теоретичних знань і вмінню застосовувати їх для розв'язання практичних завдань метод проектів набув значного поширення й успішно реалізується у світі та в Україні. У процесі проектної діяльності студенти залучаються до активної роботи шляхом послідовного виконання ними запланованих дій з метою виявлення екологічних проблем, аналізу причин їх виникнення і розроблення шляхів виходу з кризи. Проектний метод сприяє реалізації особистісного потенціалу студентів, підвищенню продуктивності їхнього навчання, а також формує у них екологічну компетенцію і відчуття відповідальності за результат своєї діяльності [13]. Такий метод навчання стимулює розвиток самостійного мислення, уміння шукати інформацію, приймати нестандартні рішення.

Під час створення самостійних проектів розвивається пізнавальна активність студентів, формуються дослідницькі й конструктивні уміння, навички аналізу інформації, добутої з різних джерел. Викладач при цьому стимулює проектну діяльність, спрямовуючи роботу студентів на досягнення кінцевого результату презентації геоекологічного проекту. Зазвичай проект оформлюється у довільній формі, залежно від творчого потенціалу виконавців, але має відповідати певним вимогам, зокрема наявності значущої проблеми і практичної цінності отриманих результатів [8]. Завдяки упровадженню методу проектів у навчальний процес студенти залучаються до практичної діяльності, закріплюючи й поглиблюючи набуті знання. У них формуються цілісні уявлення про взаємозв'язки у системі "людина - природа - господарство" та відчуття відповідальності за наслідки своєї діяльності, розвиваються ініціативність і самостійність.

Важливою умовою реалізації проектної діяльності студентів $€$ міжпредметний характер геоекологічного дослідження. Використання міждисциплінарних зв'язків для розв'язання завдань і проблем обумовлене інтегральним характером геоекології. Ці зв'язки відіграють важливу роль у підвищенні практичної й науковотеоретичної підготовки студентів, забезпечують опанування ними узагальненого характеру екологопізнавальної діяльності. Оскільки в процесі навчання студенти опановують значну кількість дисциплін, які формують різні знання й уміння, то вони мають сприйматися як єдиний взаємопов'язаний процес [17].

Проектна діяльність зазвичай здійснюється в кілька послідовних етапів (рис. 1). Перший (підготовчий) етап передбачає створення колективу виконавців і розподіл його на дослідницькі групи, визначення мети і завдань проекту, планування термінів виконання і методів роботи над ним, пошук джерел інформації. На цьому етапі обґрунтовується актуальність проблеми, підбираються адекватні методи дослідження, обговорюються варіанти використання проекту в практичних цілях. Це вимагає від студентів наукового і творчого пошуку й відповідних знань. 


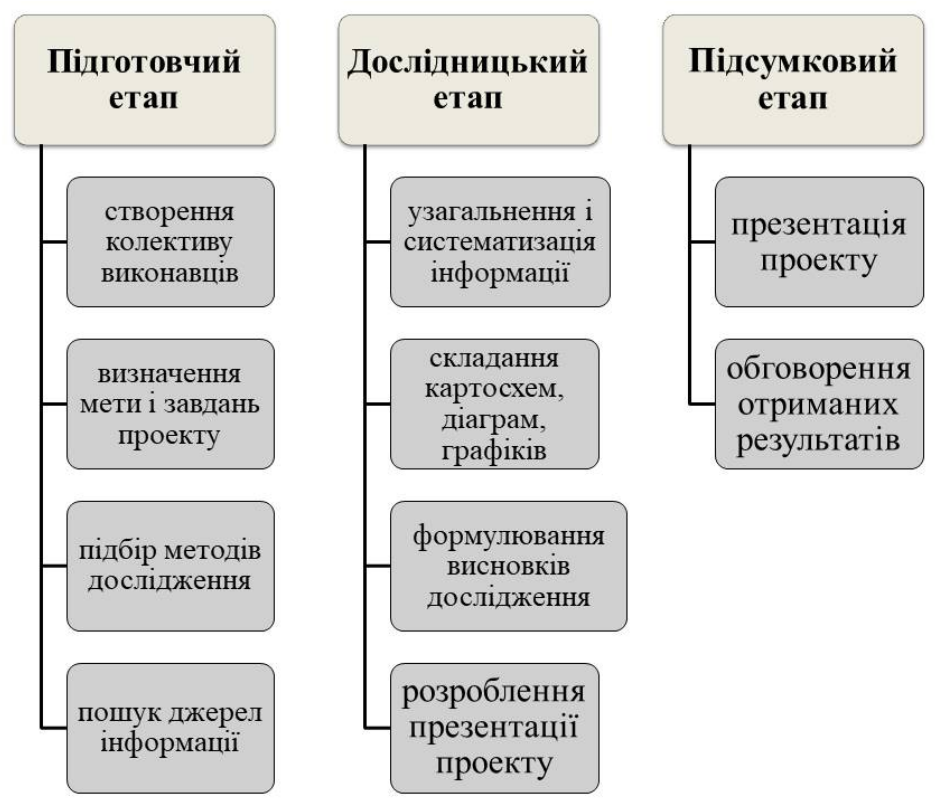

Рис 1. Структура проектної діяльності

На другому (дослідницькому) етапі розпочинається безпосередня робота над проектом: вивчення, опрацювання, узагальнення і систематизація зібраної інформації; складання картосхем, діаграм, графіків тощо; формулювання висновків дослідження у формі загального звіту й розроблення презентації проекту. На цьому етапі виявляється практична необхідність знань, отриманих на лекційних і семінарських заняттях із дисципліни "Геоекологія України" та інших пов'язаних дисциплін. Визначальне значення має організація самостійної роботи студентів, яка сприяє розвитку ініціативи, самостійності, організаторських здібностей і стимулює процес саморозвитку особистості.

На третьому (підсумковому) етапі відбувається презентація проекту. Під час презентації важливо залучити студентів групи до обговорення отриманих результатів, створити активну дискусію щодо шляхів розв'язання проблеми, установлення причинно-наслідкових зв'язків, прогнозування наслідків реалізації різних варіантів рішень. Тема проекту найчастіше пов'язана з конкретним практичним питанням, актуальним для реального життя. Предметом дослідження екологічних проектів можуть бути забруднення водойм, повітря і ґрунтів, зелена енергетика, глобальні кліматичні зміни, поводження з відходами, збереження біорізноманіття тощо. На перших курсах важливою умовою якісного екологічного проекту $€$ розроблення його для території, яка добре відома й тому небайдужа студенту - рідне місто, село чи район. Для старших студентів, особливо магістрів, теми проектів ускладнюються.

Наприклад, важливим тематичним блоком навчальної дисципліни "Геоекологія України" $\epsilon$ вивчення екологічного законодавства України. Студентам необхідно засвоїти історію становлення і сучасний стан нормативнозаконодавчої бази в галузі охорони навколишнього середовища і використання природних ресурсів. Особливу увагу слід звернути на питання, які пояснюють недієздатність системи нормативно-правового забезпечення екологізації національного шляху розвитку. Майбутні фахівці мають бути готовими до розв'язання завдань удосконалення і кодифікації екологічного законодавства відповідно до міжнародних зобов'язань України. У разі обрання теми проекту з цього тематичного блоку основними завданнями для його учасників мають бути такі:

- Проаналізувати інформаційні джерела (законодавчі акти, монографії, наукові публікації в періодичних виданнях і мережі Інтернет), присвячені аналізу екологічного законодавства України, а також плану дій щодо досягнення відповідності правової системи України acquis communautaire до критеріїв Євросоюзу.

- Систематизувати знайдену інформацію й на її основі проаналізувати зміст базових природоохоронних законів і кодексів, прийнятих за часів незалежності України, сформулювати стратегічні пріоритети України у сорері охорони природного середовища, а також розкрити причини неналежного виконання окремих екологічних програм.

- Розробити пропозиції щодо вдосконалення національного законодавства з метою його адаптації до законодавства ЄС. Обґрунтувати механізми імплементації в Україні джерел екологічного права ЄС, упровадження екосистемного підходу в управлінську діяльність і вартісної оцінки екосистемних послуг, створення екологічно обґрунтованої системи платежів за використання природних ресурсів, створення правових передумов для упровадження в Україні моделі "зеленої економіки" тощо.

- Представити результати роботи у вигляді презентації для обговорення на спеціально відведеному для цього семінарському занятті.

Оцінювання представлених проектів має враховувати повноту змісту, розкриття проблеми і розроблені пропозиції, реалізація яких не вимагатиме значних матеріальних витрат, але сприятиме розв'язанню проблеми.

Висновки і перспективи дослідження. Виходячи зі специфіки геоекології та її перетворення на самостійну фундаментальну науку, практичне втілення концепції сталого розвитку неможливе без урахування її геоекологічного змісту. Науковий вимір геоекології охоплює широкий спектр досліджень геоекосистемних взаємозв'язків для оптимізації природокористування та інтегрування здобутих знань у практику територіального планування і менеджменту. У цьому сенсі головною сферою практичного застосування результатів геоекологічних досліджень стає обґрунтування різноманітних проектів природокористування зі створенням оптимальної структурнофункціональної організації території. При цьому методи- 
ка геоекологічних досліджень базується на використанні оцінних, прогнозних, управлінських та інших методів. Метою застосування оцінних і прогнозних методів дослідження $€$ встановлення ступеня придатності геоекосистем для проектованого виду природокористування. Ці методи дослідження спрямовані передусім на запобігання можливим руйнівним природним процесам, виявлення вторинних антропогенних впливів і спричинених ними негативних змін географічного середовища. У перспективі прийняття остаточних проектно-планувальних рішень має базуватися на результатах саме оцінних і прогнозних геоекологічних досліджень.

Освітній вимір геоекології охоплює базові знання, що закладаються системою геоекологічної освіти, орієнтованої на гармонійний розвиток з урахуванням геоекологічних вимог. Викладання у вищих навчальних закладах таких дисциплін, як "Геоекологія України", "Геоекологічне обґрунтування проектів природокористування", "Геоекологічні основи раціонального природокористування" тощо, має бути націлене на усвідомлення випускниками актуальних геоекологічних проблем, які вони згодом розв'язуватимуть для забезпечення стійкого оптимального розвитку незалежної України. У найближчій перспективі доцільно ввести в навчальний процес окрему дисципліну "Прикладна геоекологія". Це дасть змогу посилити творчій характер завдань, що найліпше реалізується у проектній діяльності студентів. Використання методу проектів у навчальному процесі позитивно впливає на фрормування в студентів науководослідницьких навичок обґрунтованого прийняття рішень і загальної екологічної культури.

\section{Список використаних джерел:}

1. Арманд Д. Л. Наука о ландшафте / Д. Л. Арманд. - М., 1975.

2. Бачинский Г. А. Геоэкология как область соприкосновения географии и социоэкологии / Г. А. Бачинский // Изв. Всесоюзн. геогр. общва. - 1989. - Т. 121. - Вып. 1.

3. Бочаров В. Л. Геоэкология как наука : структурирование и тезаурус, современное состояние и перспективы развития / В. Л. Бочаров // Вестн. Воронеж. ун-та. - Сер. Геология. - 2004. - № 2.

4. Голубев Г. Н. Геоэкология : учебник / Г. Н. Голубев. - 2-е изд., испр. и доп. - М., 2006.

5. Голубев Г. Н. Основы геоэкологии : учебник / Г. Н. Голубев. 2-е изд., стер. - М., 2013

6. Жекулин В. С. Экологическая парадигма в географии и задачи Географического общества СССР / В. С. Жекулин, С. Б. Лавров, Б. С. Хорев // Изв. Всесоюзн. геогр. общ-ва. - 1987. - Т. 119. - Вып. 6.

7. Метод проектів - сучасна педагогічна технологія навчання освітніх закладів різних рівнів / О. І. Карбованець, Н. В. Куруц, Н. Б. Голуб, А. А. Майорош // Наук. вісн. Ужгород. нац. ун-ту. Сер. Педагогіка. Соціальна робота. - 2008. - Вип. 15

8. Коровіна В. А. Метод проектів як форма організації самостійної роботи студентів у процесі вивчення курсу "Екологія" [Електронний ресурс] / В. А. Коровіна. - Режим доступу : http://elibrary.kubg.edu.ua/ 3718/1/N_Korovina_APPMVPSHUGVO_IS_UKKUBG.pdf

9. Круглов І. С. Геоекологія та географія / І. С. Круглов // Наук. записки Тернопіль. держ. пед. ун-ту. Серія. Географія. - 2004. - № 2, Ч. 1

10. Мильков Ф. Н. Геоэкология и экогеография : их содержание и перспективы развития / Ф. Н. Мильков // Известия РАН. Сер. География. 1997. - № 3.

11. Морачевский В. Г Основные понятия геоэкологии / В. Г. Морачевский, К. М. Петров // Основы геоэкологии. - СПб., 1994
12. Розанов Л. Л. Методологический аспект геоэкологии / Л. Л. Розанов // Вестн. МГОУ. Сер. Естественные науки - 2015 - № 2.

13. Совгіра С. В. Методика навчання екології : навч. посіб.практикум / С. В. Совгіра. - 3-тє вид. - Умань, 2016.

14. Сочава В. Б. География и экология / В. Б. Сочава // Матер. V съезда Геогр. общ-ва Союза ССР. - 1970.

15. Топчиев А. Г. Геоэкология : Географические основы природопользования / А. Г. Топчиев. - Одесса, 1996

16. Тролль К. Ландшафтная экология (геоэкология) и биогеоценология. Терминологическое исследование / К. Тролль // Изв. АН СССР. Сер. Геогр. - 1972. - № 3.

17. Чайковська Г. Б. Проектні технології як ефективний засіб формування екологічної культури студентів / Г. Б. Чайковська // Наук. записки ТНПУ імені Володимира Гнатюка. Сер. Педагогіка. - 2017. - № 3.

18. Шищенко П. Г. Геоекологія України: підручник / П. Г. Шищенко, О. П. Гавриленко. - К., 2017.

19. Ясаманов Н. А. Основы геоэкологии : уч. пос. / Н. А. Ясаманов. - M., 2003.

20. Forman R. T. T. Landscape ecology / R. T. T. Forman, M. Godron. - New York, 1986.

\section{References:}

1. Armand, D.L. (1975). Nauka o landshafte. - Moscow

2. Bachinskiy, G.A. (1989). Geoekologiya kak oblast soprikosnoveniya geografii i sotsioekologii // Izvestiya Vsesoyuznogo geograficheskogo obschestva. T. 121. Vyip. 1

3. Bocharov, V.L. (2004). Geoekologiya kak nauka : strukturirovanie ezaurus, sovremennoe sostoyanie i perspektivyi razvitiya / V.L. Bocharov // Vestnik Voronezhskogo universiteta. Ser. geologiya. No 2.

4. Golubev, G.N. (2006). Geoekologiya : uchebnik. - Moscow.

5. Golubev, G.N. (2013). Osnovyi geoekologii : uchebnik. - Moscow.

6. Zhekulin, V.S., Lavrov, S.B., Horev, B.S. (1987). Ekologicheskaya paradigma $v$ geografii i zadachi Geograficheskogo obschestva SSSR /I Izvestiya Vsesoyuznogo geograficheskogo obschestva. T. 119. Vyip. 6.

7. Karbovanets, O.I., Kuruts, N.V., Holub, N.B. Maiorosh, A.A. (2008). Metod proektiv - suchasna pedahohichna tekhnolohiia navchannia osvitnikh zakladiv riznykh rivniv // Naukovyi visnyk Uzhhorodskoho natsionalnoho universytetu. Seriia Pedahohika. Sotsialna robota. Vyp. 15.

8. Korovina, V.A. Metod proektiv yak forma orhanizatsii samostiinoi roboty studentiv u protsesi vyvchennia kursu "Ekolohiia" // Elektronnyi resurs. Rezhym dostupu: http://elibrary.kubg.edu.ua/3718/1/V_Korovina_ APPMVPSHUGVO IS UKKUBG.pdf.

9. Kruhlov, I.S. (2004). Heoekolohiia ta heohrafiia // Naukovi zapysky Ternopilskoho derzhavnoho pedahohichnoho universytetu. Seriia: heohrafiia. No 2. Ch. 1.

10. Milkov, F.N. (1997). Geoekologiya i ekogeografiya : ih soderzhanie i perspektivyi razvitiya // Izvestiya RAN. Seriya "Geografiya". No 3.

11. Morachevskiy, V.G , Petrov, K.M. (1994). Osnovnyie ponyatiya geoekologii // Osnovyi geoekologii. Sankt-Petrburg.

12. Rozanov, L.L. (2015). Metodologicheskiy aspekt geoekologii // Vestnik MGOU. Seriya : Estestvennyie nauki. No 2.

13. Sovhira, S.V. (2016). Metodyka navchannia ekolohii : navch. posibnyk-praktykum. 3-tie vyd. Uman.

14. Sochava, V.B. (1970). Geografiya i ekologiya // Materialyi V s'ezda Geograficheskogo obschestva Soyuza SSR.

15. Topchiev, A.G. (1996). Geoekologiya : Geograficheskie osnovyi prirodopolzovaniya. - Odessa.

16. Troll, K. (1972). Landshaftnaya ekologiya (geoekologiya) i biogeotsenologiya. Terminologicheskoe issledovanie // Izvestiya AN SSSR. Seriya geografiya. No 3 .

17. Chaikovska, H.B. (2017). Proektni tekhnolohii yak efektyvnyi zasib formuvannia ekolohichnoi kultury studentiv // Naukovi zapysky TNPU imeni Volodymyra Hnatiuka. Seriia : Pedahohika. No 3.

18. Shyshchenko, P.H, Havrylenko, O.P. (2017). Heoekolohiia Ukrainy : pidruchnyk. - Kyiv.

19. Yasamanov, N.A. (2003). Osnovyi geoekologii : uch. pos. Moscow. York.

20. Forman, R.T.T., Godron, M. (1986). Landscape ecology. - New

Надійшла до редколегії 04.05.18

П. Шищенко, д-р геогр. наук, проф.,

Е. Гавриленко, канд. геогр. наук, доц.

Киевский национальный университет имени Тараса Шевченко, Киев, Украина

\section{ГЕОЭКОЛОГИЯ В НАУЧНО-ОБРАЗОВАТЕЛЬНОМ ИЗМЕРЕНИИ}

Рассмотрено становление геоэкологической парадигмы, а также разное толкование содержательной сущности геоэкологии. Проанализированы задания междисциплинарной геоэкологии и ее прикладной антропоцентрический аспект, на основе которого должны фоормироваться проектно-планировочные решения. Раскрыты методы оценочных и прогнозных геоэкологических исследований, которые служат установлению степени пригодности геоэкосистем для разных видов деятельности и обоснования проектов природопользования. Исходя из важности усвоения студентами знаний о дестабилизации природной среды как природно-техногенного целого, обоснована целесообразность преподавания прикладной геоэкологии как отдельной учебной дисциплины. Раскрыты содержание и последовательность применения инновационных активных методов в учебном процессе, в частности метода проектов. Приведен пример проектной деятельности студентов в случае избрания конкретной темы проекта по дисциплине "Геоэкология Украины".

Ключевые слова: геоэкосистемы, геоэкологическое оценивание и прогнозирование, обоснование проектов природопользования, метод проектов, геоэкологическое образование. 
P. Shyshchenko, Doctor of Science in Geography, Professor, O. Havrylenko, PhD Geography, Associate Professor

Taras Shevchenko National University of Kyiv, Kyiv, Ukraine

\section{GEOECOLOGY IN THE SCIENTIFIC AND EDUCATIONAL DIMENSION}

Geoecological paradigm incipience has formed an interdisciplinary geoecology, which purpose is to optimize the nature using on the basis of geoecosystem interconnections study and integration of the acquired knowledge into the practice of territorial planning and management. An important sphere of geoecological research practical application results is the creation of an optimal structural and functional organization of the territory for substantiation of various nature management projects. With the help of estimating and predictive research methods, the degree of geoecosystems suitability for the projected nature using kinds is established. Forecast geoecological researches are aimed at preventing possible destructive natural processes, identifying anthropogenic influences and caused by the negative changes in the natural environment. On the results of evaluative and forecast geoecological research, the adoption of final design and planning decisions should be based. Based on results of the conducted research the following conclusions have been made:

1. The priority task of applied geoecology is to prevent the emergence of crisis and emergency geoecological situations. Therefore, in the near future, it would be expedient to teach applied geoecology a separate academic discipline.

2. Solving the constructive tasks of geoecological research requires the corresponding specialty and education of researchers.

3. Basic geoecological knowledge is laid out by the educational system with the use of innovative active methods in the educational process, in particular, the project method. For this purpose, the discipline "Geoecology of Ukraine" is taught at the Faculty of Geography of the Kyiv Taras Shevchenko National University for masters of the first year of study.

4. The lecturer stimulates the project activity, directing the work of students to achieve the final result - the geoecological project presentation. For example, the implementation of the project on discipline "Geoecology of Ukraine" involves students fulfilling such basic tasks - search, analysis and systematization of information; choice of research methods; drawing up of maps, diagrams, charts; formulating the conclusions of the study and developing the presentation of the project.

5. The topic of the project is most often associated with specific practical issues relevant to real life. The study of the discipline "Geoecology of Ukraine" promotes orientation of students for the specialty of the environmental manager, designer, expert on environmental projects, etc.

Keywords: geoecosystems, geoecological estimation and forecasting, substantiation of nature management projects, project method, geoecological education.

О. Бейдик, д-р геогр. наук, профр. Київський національний університет імені Тараса Шевченка, Київ, О. Топалова, канд. геогр. наук Мелітопольський державний педагогічний університет імені Богдана Хмельницького, Мелітополь

\section{ТЕОРЕТИКО-ПРАКТИЧНІ АСПЕКТИ РЕКРЕАЦІЙНО-ТУРИСТИЧНОГО ПРИРОДОКОРИСТУВАННЯ}

Розглянуто природокористування як одна з прикладних наукових галузей, що базується на природонаукових знаннях і комплексі фундаментальних суспільно-економічних дисциплін, з одного боку, а з іншого - як розгалужена і потужна практика та суспільний досвід використання природних умов природних ресурсів. Розкрито основні етапи наповнення та структуру програми 3 природокористування, яка складена відповідно до освітньо-професійної програми підготовки фахівців за освітньо-кваліфікаційним рівнем "магістр" з напряму підготовки "Сфера обслуговування" за спеціальністю "Туризмознавство". Наведено низку структурно-логічних моделей з обраної тематики. Проведені дослідження та якісне оцінювання природних компонентів у межах НПП України можуть компенсувати неповний реєстр даних ресурсної бази адаптивного туризму та стати своєрідною "дорожньою картою" при реалізації різноманітних туристсько-адаптивних програм для маломобільної категорії населення.

Ключові слова: природокористування, структурно-логічне моделювання, адаптивний туризм.

Вступ. Постановка проблеми. Природокористування $€$ одним з наріжних каменів успішного функціонування економіки будь-якої країни, а економічний та суспільно-географічний аналіз (оцінювання) природних ресурсів - одним із пріоритетів їх ефективного використання. Дисципліни з природокористування та рекреаційно-туристичного природокористування у ВНЗ України (географічні, геолого-географічні, природно-географічні фракультети національних, педагогічних університетів) $є$ базовими впродовж багатьох років. Наприклад, на географрічному фракультеті КНУ (кафедра країнознавства та туризму) викладається нормативна навчальна дисципліна "Теорія та практика рекреаційнотуристичного природокористування", яка складена відповідно до освітньо-професійної програми підготовки фахівців за освітньо-кваліфікаційним рівнем "магістр" 3 напряму підготовки "Сфера обслуговування" за спеціальністю "Туризмознавство".

Аналіз останніх досліджень і публікацій. Теоретико-практичним питанням природокористування присвячені роботи М. Ф. Реймерса, С.П. Хромова, О.И. Чеботарьова, Г.С.Горшкова, О. Є. Криволуцького, комплексному економічному оцінюванню природних ресурсів як одному з головних факторів розвитку та розміщення виробничих сил - публікації й монографії
О. О. Мінца, А. Г. Аганбегяна, Е. Б. Алаєва, оцінці природно-ресурсного потенціалу - монографії В. П. Руденка, М.Г. Ігнатенка, аналізу природних рекреаційнотуристичних ресурсів - піонерні роботи Л.І. Мухіної, В. С. Преображенського, Ю. О. Веденіна, Б. М. Ліханова, І. В. Зоріна, О. О. Бейдика. За М.Ф. Реймерсом (1990) [7] природокористування двоєдине: 1) це одна 3 прикладних наукових галузей, що базується на природонаукових знаннях і комплексі фундаментальних суспільно-економічних дисциплін; 2) це розгалужена і потужна практика та суспільний досвід використання природних умов природних ресурсів. О. О. Мінц [5] розглядає питання економічної оцінки природних ресурсів теоретично як загальнішу проблему взаємодії природи і суспільства, а також практично - як стратегію розвитку національної економіки.

Викладення основного матеріалу. Наповнення та структура програми з природокористування. Об'єктом вивчення дисципліни є природні рекреаційнотуристичні ресурси або природні умови, які оцінені економічно або іншим чином і залучені до рекреаційнотуристичної сфери. Предметом вивчення навчальної дисципліни $є$ просторова організація, оцінювання, класифікація та інші аспекти рекреаційно-туристичного природокористування. Мета і завдання дисципліни ви- 